Microbial, chemical and sensory evaluation of pigeon pea condiment from wild and controlled fermentation

M.A. Balogun*, R.N. Ahmed, O.A. Akintayo, T.E. Aruna, M.O. Omovbude and T. Shittu

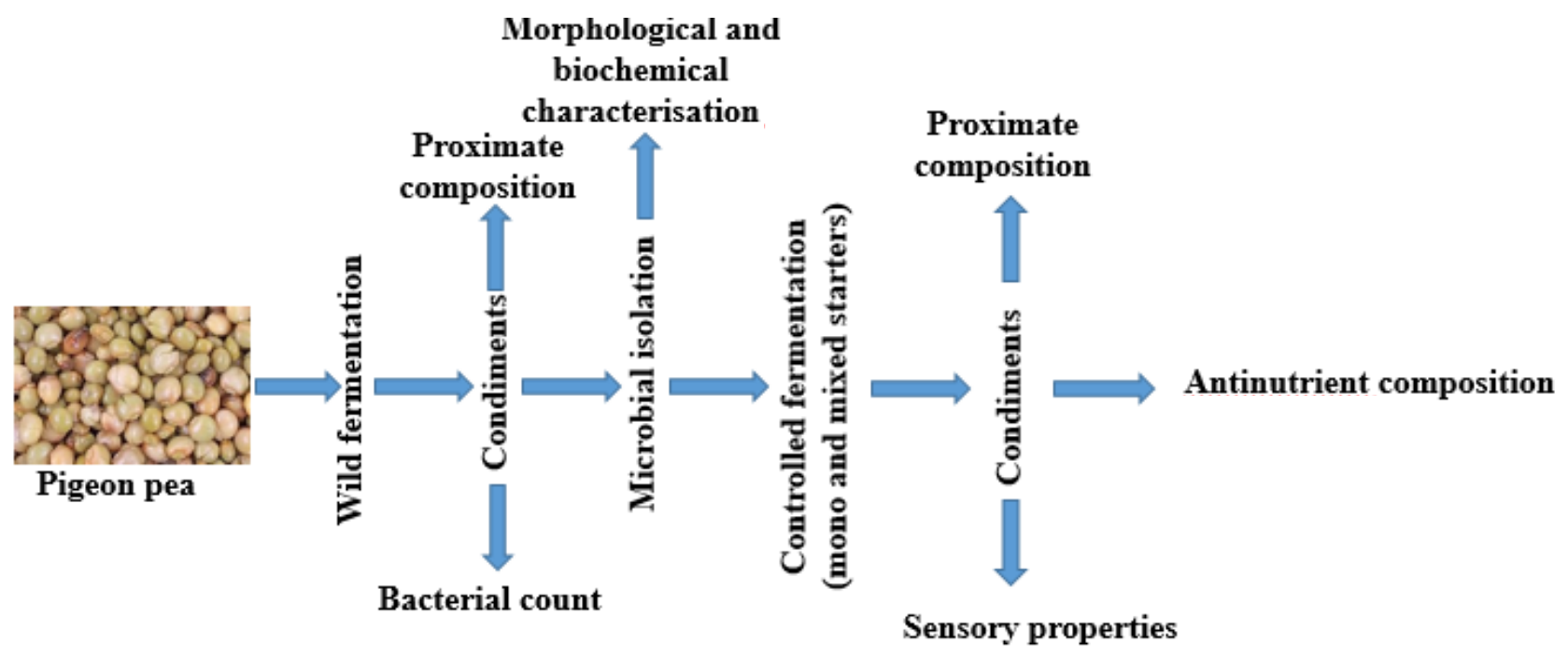

Highlights

- Chemical changes of pigeon pea during wild and controlled fermentation were studied.

- Isolates used for controlled fermentation were Bacillus and Lactobacillus species.

- Higher protein found with 72 hour controlled fermentation than with 96 hour wild fermentation.

- Antinutrients analysed showed reduction with increasing fermentation period.

- Higher sensory ratings found for condiment from controlled fermentation than from wild process. 
RESEARCH ARTICLE

\title{
Microbial, chemical and sensory evaluation of pigeon pea condiment from wild and controlled fermentation
}

\author{
M.A. Balogun ${ }^{1, *}$, R.N. Ahmed ${ }^{2}$, O.A. Akintayo ${ }^{1}$, T.E. Aruna ${ }^{3}$, M.O. Omovbude ${ }^{1}$ and T. Shittu ${ }^{1}$ \\ ${ }^{1}$ Department of Home Economics and Food Science, University of Ilorin, Ilorin, PMB 1515, Nigeria. \\ ${ }^{2}$ Department of Microbiology, University of Ilorin, Ilorin, PMB 1515, Nigeria. \\ ${ }^{3}$ Department of Food Science and Technology, Kwara State University, Malete, Nigeria.
}

Received: 13/09/2020; Accepted: 15/06/2021

\begin{abstract}
Pigeon pea (Cajanus cajan L.) is an important grain legume crop predominantly grown in India. Changes in the microbial and chemical qualities of pigeon pea during wild $(96 \mathrm{~h})$ and controlled $(72 \mathrm{~h})$ fermentations were investigated. Sensory properties of the resulting condiments were also evaluated. Organisms associated with $96 \mathrm{~h}$ wild fermentation of pigeon pea included Bacillus species, Lactobacillus species, Staphylococcus aureus, Escherichia coli, Escherichia faecalis and Pseudomonas aeruginosa. $\mathrm{pH}$ decreased with wild (from 7.5 to 5.0) and controlled (from 7.4 to 6.0) fermentations. There was a steady decrease in crude fibre, crude fat and carbohydrate but an increase in ash, moisture and crude protein with increasing length of fermentation periods. Phytate, oxalate, tannins, and trypsin inhibitory activity of fermented condiment decreased with increasing fermentation period. Sensory evaluation showed that pigeon pea produced from controlled fermentation had higher scores in colour and texture compared with commercial condiment (iru). This study has revealed the feasibility of producing pigeon pea condiment using wild and controlled fermentation, and this presents a veritable strategy to increase the utilization of the crop.
\end{abstract}

Keywords: pigeon pea; food condiment; changes; wild; controlled; fermentation.

\section{INTRODUCTION}

Pigeon pea (Cajanus cajan L.) is an important grain legume crop predominantly grown in India (Mathews and Saxena, 2005 ) but also grown in many parts of Nigeria. It is known as otili in South-west Nigeria where the seeds are boiled and eaten by the natives. It is one of the lesser-known legume seed crops in Nigeria which is easy to grow. It is an economically and nutritionally important legume and a major source of protein for the poor communities of many tropical and sub-tropical regions of the world (Sharma et al., 2011). Pigeon pea seeds contain about 57 - 58\% carbohydrate, 17 - $28 \%$ protein, $1.2-8.1 \%$ crude fibre, 0.6 $3.8 \%$ fat, and are a rich source of dietary minerals (calcium, magnesium, phosphorus, potassium, iron and sulphur) as well as water soluble vitamins (thiamine. riboflavin, niacin and choline) (Akande et al., 2010). Studies also showed that the protein of pigeon pea is rich in lysine (Adebowale and Maliki, 2011) but low in sulfur amino acids, methionine and cysteine (Akande et al., 2010).
As part of recent efforts to promote the utilization of lesser-known food crops, different legumes are being fermented for incorporation into foods as condiments. Aside from improving the sensory quality of foods, these condiments are believed to improve the nutritional and dietary status of the population. They are normally not eaten as a principal food during a meal but are mostly added to other foods to improve or alter the flavor (flavor enhancers) in many traditional dishes including sauces and soups (Azokpota et al., 2006). Condiments can also act as texture enhancers and, in some cultures, as a complement to a main dish. Due to their nutrient compositions, condiments are mostly used as meat supplements (non-meat proteins) and also as functional ingredients in fermented foods.

There are several reports on the production of locally fermented condiments using different legumes and oil seeds like African locust bean (iru), African mesquite (Okpehe), melon seed (ogiri) and soybean (daddawa) (Balogun et al., 2017). These locally fermented condiments are rich, but cheap sources of plant protein that can be afforded by the rural populace. The methods employed in the production of fermented condiments vary with regions, as well as socioeconomic circumstances. Fermented condiments are prepared traditionally in homes through uncontrolled solid-substrate fermentation using rudimentary utensils under various unhygienic conditions (Balogun and Oyeyiola, 2012). This traditional method carried out under various unhygienic conditions results in variations in the quality and stability of the product. The use of starter cultures (controlled fermentation) does not only help to reduce fermentation time, but also guarantees food quality, consistency and safety (Achi, 2005; Balogun et al., 2017). Organisms that have been used as either mono or mixed cultures in the fermentation of various condiments include the following genera: Bacillus, Staphylococcus, Enterobacter, Streptococcus, Micrococcus and Leuconostoc ( Enujiugha, 2010; Balogun et al., 2017; Adebayo et al., 2018). 
The use of pigeon pea in the production of a fermented condiment will improve its economic utilization, increase variety of locally fermented condiments and can help reduce protein malnutrition in developing countries. Information on the fermentation of pigeon pea for condiment production either using wild or controlled fermentation is scanty. The aim of this study therefore was to produce pigeon pea condiment first through wild fermentation, then through use of starters, cultured from isolated microorganisms. Physicochemical and sensory attributes of the pigeon pea condiments produced were also determined.

\section{MATERIALS AND METHODS}

\section{Collection of raw materials}

Fresh pigeon pea seeds (creamy white variety) were obtained from a farm in Ilofa, Nigeria, authenticated at the herbarium of the Plant Biology Department of the University of Ilorin with voucher specimen number UILH/001/565.

\section{Wild fermentation of pigeon pea for condiment production}

Production of pigeon pea condiment was done using the method described by Balogun and Oyeyiola (2012) with some modifications. Three hundred grams of the seeds were sorted and moistened with $50 \mathrm{~mL}$ of water. The moistened seeds were left to equilibrate for $15 \mathrm{~min}$. The seeds were then roasted on an electric fryer (Beckers, Model F1-C, Italy) for $10 \mathrm{~min}$ at $150{ }^{\circ} \mathrm{C}$ while the seeds were being continuously turned. The roasted seeds were boiled for $2 \mathrm{~h}$ in a stainless steel pot on a laboratory hot plate, resulting in soft and swollen seeds. The boiling water was decanted while the seeds were allowed to cool at ambient temperature $\left(27 \pm 2{ }^{\circ} \mathrm{C}\right)$ such that the residual seed coats were easily removed by pressing between gloved fingertips. The dehulled seeds were washed with clean water and the seed coats later decanted along with the washing water, leaving the seed cotyledons clean. The clean cotyledons were cooked in distilled water for $30 \mathrm{~min}$ on a laboratory hot plate set at $60{ }^{\circ} \mathrm{C}$. These were drained using a clean muslin cloth and wrapped with properly washed and disinfected banana leaves. The wrapped cotyledons were covered with two layers of sterile aluminum foils, placed in a clean container, and incubated in an incubating unit at $30 \pm 2{ }^{\circ} \mathrm{C}$ for $96 \mathrm{~h}$ for fermentation to take place. The fermentation period was selected based on preliminary trials. After $72 \mathrm{~h}$, the condiment had not adequately softened nor developed noticeable characteristic flavour, so the fermentation was extended for another day. Samples were taken at 0, 24, 48, 72 and $96 \mathrm{~h}$ for analyses.

\section{Production of pigeon pea condiment using starter cultures}

Isolates obtained from the wildly fermented samples were used to inoculate a new batch of processed pigeon pea cotyledons as described above. The isolates (mono and mixed cultures) that produced the highest value of crude protein were taken for subsequent inoculation into the processed pigeon pea cotyledons. The inoculation of isolates as starter organisms was done following a previously described method (Balogun et al., 2014). A suspension of each of Lactobacillus and Bacillus in nutrient broth $(1 \mathrm{~mL})$ was used to inoculate $200 \mathrm{~g}$ of the unfermented cotyledons of pigeon pea in monoculture while the mixed culture was in ratio 1:1 of the inoculants (Balogun et al., 2014). After inoculation, the resultant mash was placed in banana leaves which had been disinfected with $75 \%$ ethyl alcohol and rinsed with sterile water. Two layers of aluminum foil were used to wrap the mash, thereafter it was incubated at 30 $\pm 2{ }^{\circ} \mathrm{C}$ for different fermenting regimes, starting from the $0^{\text {th }} \mathrm{h}$ (time of wrapping) and ending at the $72^{\text {nd }} \mathrm{h}$. Earlier trials before the main study had shown that controlled fermentation when done for 96 hours made the condiment too mushy, while 72 hours was preferred. Samples were taken at $0,24,48$ and $72 \mathrm{~h}$ for analyses.

\section{Isolation and identification of microorganisms}

The method of isolation as described by Balogun and Oyeyiola (2011) was used. Briefly, at every $24 \mathrm{~h}$ interval, one gram of each fermented pigeon pea sample was aseptically taken for serial dilutions $\left(10^{-1}, 10^{-2}, 10^{-3}, 10^{-4}, 10^{-5}\right.$ and $\left.10^{-6}\right)$. A loopful $(0.1 \mathrm{~mL})$ of each dilution was then incubated $\left(37^{\circ} \mathrm{C}\right.$ for $\left.24 \mathrm{~h}\right)$ on a nutrient agar. Thereafter, developed colonies were counted and identified, and also observed for colonial characteristics. Pure cultures obtained from these were subjected to Gram-staining and biochemical tests (oxidase, catalase, indole, citrate utilization, methyl red, Voges Proskauer, sugar fermentation and urease). Identified isolates were matched with the Bergey's Manual of Determinative Bacteriology (Krieg and Holt, 1984; Astuti, 2016) for confirmation.

Determination of chemical properties of pigeon pea condiment produced from wild and controlled fermentations

\section{Proximate analysis}

Standard method of the A.O.A.C. (2005) was used to determine the proximate compositions (moisture, crude fat, ash and crude fibre) of the fermented pigeon pea condiments. Protein content was determined by the Kjeldahl method $(\mathrm{N} \times 6.25)$ while carbohydrate was calculated by difference.

$p H$

Ten grams (10 g) of the sample was dissolved in $100 \mathrm{~mL}$ of distilled water in a beaker and this was thoroughly shaken to obtain a homogeneous mixture. The $\mathrm{pHs}$ of the samples were determined using a $\mathrm{pH}$ meter (Model 3520, Bibby Scientific Limited Dumow Essex, UK). The $\mathrm{pH}$ meter was calibrated with $\mathrm{pH} 4.0$ and $\mathrm{pH} 7.0$ buffer solutions prior to its use for the samples.

\section{Anti-nutritional factors offermented pigeon pea condiment}

The phytate was determined using the method described by (Omoboyowa et al., 2015). The trypsin inhibitor activity was determined according to the method described by Prokopet and Unlenbruck (2002). The tannin was determined using method described by Jaffe (2003) while 
oxalate was determined using the method described by Munro and Bassir (1969).

\section{Sensory evaluation of fermented pigeon pea condiment}

Sensory evaluation was carried out using fifty semitrained panelists. Soups were prepared with the laboratoryproduced pigeon pea condiments (from wild and controlled fermentations) while a control sample was prepared with a commercial condiment (iru). The panelists were selected from among staff and students of the Department of Home Economics and Food Science, University of Ilorin who are familiar with the quality attributes of fermented condiment. They were instructed to rate the samples in terms of colour, aroma, taste and overall acceptability using a 9-point hedonic scale of preference where 9 indicated "like extremely" and 1 indicated "dislike extremely".

\section{Statistical analysis}

Results obtained from the analyses above were subjected to statistical analyses (i.e., ANOVA and Duncan test) using Statistical Package for Social Science (SPSS), version 16.0 for Windows (SPSS Inc., Chicago, USA).

\section{RESULTS AND DISCUSSIONS}

\section{Colony morphology and biochemical characteristics of isolated bacteria}

A total of six bacterial species were obtained (Table 1). After characterization and identification based on morphological, microscopic and biochemical test, the isolates were identified as Bacillus sp., Lactobacillus sp., Escherichia coli, Escherichia feacalis, Pseudomonas aeruginosa, and Staphylococcus aureus. This result is consistent with the work of Afolabi et al. (2016) who reported that organisms involved in the fermentation of soya bean to produce soyiru are mostly Bacillus specie, lactic acid bacteria and Staphylococcus species. The presence of different organisms isolated from this study can be explained from the fact that the mechanism of fermentation in any food matrix is a complex microbiological process involving interactions between different microorganisms (Olasupo et al., 2016). The contribution of the associating flora of fermenting substrates depends on the composition and hygienic state of the substrate during production. Olasupo et al. (2016) noted that the microbial actions on substrate fermented using wild process are determined by the microbial status of the substrates, utensils, handlers and the production environment. During fermentation, the microorganisms use the nutritional components of the seeds, converting them into products that contribute to the chemical composition and flavour of the condiment. Fresh fruits and vegetable often carry high levels of these organisms as part of their normal flora (Achi, 2005).

Microbial population of the isolates as represented in Table 2 revealed that Lactobacillus and Bacillus species were predominant throughout the fermentation period and this may be due to their ability to grow rapidly in food materials. Bacillus species are spore forming bacteria

Table 1: Colony morphology and biochemical characteristics of bacteria isolated from wild fermentation of pigeon pea seeds.

\begin{tabular}{|c|c|c|c|c|c|c|}
\hline Parameters & $\begin{array}{c}\text { Lactobacillus } \\
\text { species }\end{array}$ & $\begin{array}{c}\text { Staphylococcus } \\
\text { aureus }\end{array}$ & $\begin{array}{c}\text { Escherichia } \\
\text { coli }\end{array}$ & $\begin{array}{c}\text { Pseudomodas } \\
\text { aeruginosa }\end{array}$ & $\begin{array}{c}\text { Escherichia } \\
\text { feacalis }\end{array}$ & $\begin{array}{c}\text { Bacillus } \\
\text { species }\end{array}$ \\
\hline Gram Reaction & + & + & - & - & + & + \\
\hline Morphology & Coccus & Coccus & Rod & Rod & Coccus & Rod \\
\hline Cell Arrangement & Pairs/chains & Irregular/cluster & Single & Single & Pairs/chains & Pairs/chains \\
\hline Pigmentation & - & - & - & $\begin{array}{l}\text { Reddish } \\
\text { orange }\end{array}$ & - & - \\
\hline Motility & - & - & - & - & - & - \\
\hline Spores (endospores) & - & - & - & - & - & + \\
\hline Catalase & - & + & + & + & + & + \\
\hline Oxidase & - & - & - & + & - & - \\
\hline Indole & - & - & + & - & + & - \\
\hline Coagulase & - & + & - & - & - & - \\
\hline Urease & - & + & + & - & - & - \\
\hline Citrate utilization & - & + & - & + & - & + \\
\hline VP & + & + & - & - & + & + \\
\hline MR & - & + & - & - & + & - \\
\hline Glucose & + & + & + & - & + & + \\
\hline Sucrose & + & + & + & - & + & + \\
\hline Lactose & + & + & + & - & + & - \\
\hline Gas production & - & - & + & - & - & - \\
\hline
\end{tabular}


known for their capability to ferment sugars while the lactic acid bacteria have unique metabolic attributes (Odion-Owase et al., 2018). They were identified as the major microorganisms in the fermentation of African oil bean seed in the production of ugba (a product of alkaline fermentation of oil bean seeds) where they are believed to readily associate with the cotyledon at the beginning of fermentation (Olasupo et al., 2016). Lactobacillus and Bacillus counts increased consistently throughout the fermentation period. There were reductions in the microbial count of the other four isolates as fermentation progressed to the $72^{\text {nd }}$ hour and were no longer present at the $96^{\text {th }}$ hour. This may be attributed to the possible release of inhibitory compounds by Lactobacillus and/or Bacillus species on one hand, and the changing chemical composition of the fermenting substrate on the other hand. For example, Bacillus species have been recognised with the ability to produce antimicrobial compounds, inhibitory to the growth of pathogenic microorganisms (Compaoré et al., 2013; Ben-Harb et al., 2019). Similarly, it has been noted that some pathogenic and/or spoilage microorganisms including Staphylococcus are inhibited by lactic acid bacteria, a phenomenon that can be generally linked with acidification (Ben-Harb et al., 2019), and precisely lactic acid production (Tamang et al., 2015). Again, it is possible that the changing chemical composition of the pigeon pea during fermentation no longer supported the nutritional requirements of the affected microorganisms. This is plausible as Achi, (2005) had earlier reported that the activity of the accompanying flora of a substrate is a function of the chemical composition of that substrate. The author further noted that during fermentation, microorganisms utilize nutrients in a substrate and convert them to products that modify its chemical composition. Apart from the liberation of inhibitory products and changing chemical composition, other possible factors include modified environmental conditions such as temperature and $\mathrm{pH}$ above or below the tolerance level of the organisms.

\section{Crude protein of pigeon pea condiments produced using controlled fermentation}

The highest crude protein was observed in the sample fermented with a combination of Bacillus and Lactobacillus species (BL) while the sample fermented with only Lactobacillus species had the least value after $96 \mathrm{~h}$ of fermentation (Figure 1A). The high crude protein content of sample BL may have resulted from using mixed culture of the isolates (Bacillus and Lactobacillus) which were given equal chance to act on the substrate. This can be associated to accelerated rates that accompany the growth of microorganisms in mixed cultures. For example, higher growth rate was observed when $B$. subtilis was co-cultured with Staphylococcus epidermidis compared to when it was cultured alone (Olanbiwoninu and Odunfa, 2018). Fermentation of most food products depend on the mixture of microorganisms which work together in agreement to produce a product that has the desired characteristics. The result obtained in this study is consistent with the findings of Balogun et al. (2017) who reported high crude protein content when mixed culture of Bacillus subtilis and Bacillus licheniformis were used to ferment Prosopis africana seeds.

\section{Effect of wild and controlled fermentations on the $\mathrm{pH}$ of pigeon pea condiment}

There was a significant $(p<0.05)$ decrease in the $\mathrm{pH}$ for both wild and controlled fermentations of pigeon pea as fermentation days increased from 0 to $96 \mathrm{~h}$ (Figure 1B). The result obtained is consistent with the report of Oyarekua (2011) in the production of fermented pigeon pea flour where a decrease in $\mathrm{pH}(6.8$ - 4.2) was observed at the end of fermentation period. Though reports in literature indicate that the fermentation of leguminous seeds for condiment production results in predominant generation of alkaline products, such as ammonia (Olasupo et al., 2016; Balogun et al., 2017), findings from this study present some deviation. While the reason for this contrary observation remains yet to be determined, it can be hypothesized that acidic compounds, such as lactic acid, were the major metabolites. Ajatta et al. (2018) found that the $\mathrm{pH}$ of kidney bean during a 4-day fermentation initially increased from 6.43 to 7.68 after the first day, but decreased to 5.46 at the end of fermentation. The authors attributed this to the colonizing microorganisms, whose activities presumably generated more acidic products.

\section{Effect of wild and controlled fermentations on the proximate composition of pigeon pea condiment}

There was a significant increase in the moisture content of fermented pigeon pea condiment during both the wild and controlled fermentations (Tables 3 and 4). Moisture content may increase with metabolic activity of microbe such as fermentation (Chukwu et al., 2010). Increase in the moisture content of leguminous seeds during fermentation may justify their corresponding softer texture. Different moisture levels have been reported for condiments from different leguminous sources in literature. For example, Chukwu et al. (2010) reported an increase in the moisture content of locust bean (from 7.01\% to $37.10 \%$ ) following 48-hour fermentation. Meanwhile lower figures (9.7 10.74) were reported while tamarinds were fermented for 1-3 days (Olagunju et al. 2018). These variations in moisture may be associated with differences in substrate sources and lengths of fermentation used.

Crude protein of the pigeon pea increased from for both wild and controlled fermentation (Tables 3 and 4). Increase in protein might be the result of an increasing microbial mass during fermentation, as well as their concomitant hydrolytic actions on proteins, which liberated more amino acids and peptides (Ajatta et al., 2018). The higher crude protein obtained from controlled than wild fermentation may be attributed to the combined use of Bacillus and Lactobacillus as starter organisms for fermentation. A similar study showed a higher protein content (44.61\%) for Prosopis africana seeds when fermented with a mixed starter culture containing Bacillus subtilis and Bacillus licheniformis than when fermentation was carried out wildly (41.25\%) (Balogun et al., 2017). Implication of this is that the use of starter organisms in 

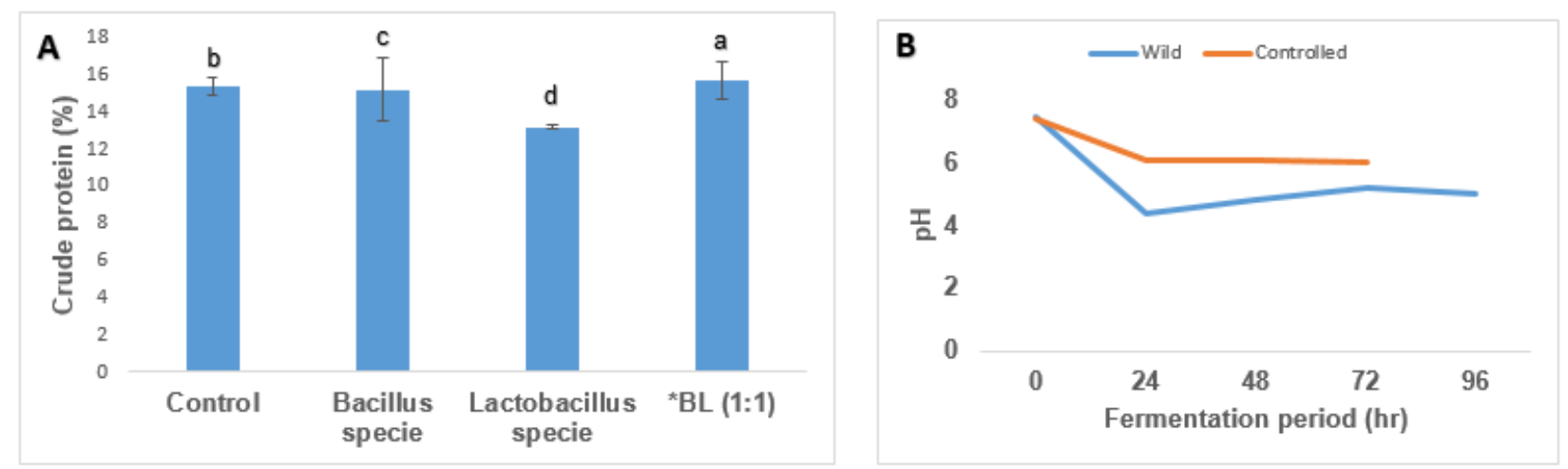

Figure 1: A) Crude protein content of pigeon pea seeds fermented using mono and mixed cultures and B) Changes in pH during wild and controlled fermentations of pigeon pea seeds.

Note: Error bars represent S.D. $(\mathrm{n}=3)$; BL (1:1) represent mixed culture of Bacillus and Lactobacillus species in ratio 1 to 1 .

Table 2: Total count $(\mathrm{cfu} / \mathrm{mL})$ of bacterial isolates.

\begin{tabular}{cccccc}
\hline Bacterial Isolates & \multicolumn{5}{c}{ Duration (h) } \\
\cline { 2 - 6 } & $\mathbf{0}$ & $\mathbf{2 4}$ & $\mathbf{4 8}$ & $\mathbf{7 2}$ & $\mathbf{9 6}$ \\
\hline Lactobacillus & $4.2 \times 10^{8}$ & $6.2 \times 10^{8}$ & $8.4 \times 10^{8}$ & $1.0 \times 10^{9}$ & $1.4 \times 10^{10}$ \\
S. aureus & $9.3 \times 10^{8}$ & $8.4 \times 10^{8}$ & $2.6 \times 10^{5}$ & $1.8 \times 10^{1}$ & $\mathrm{ND}$ \\
E. coli & $8.4 \times 10^{8}$ & $7.2 \times 10^{6}$ & $6.3 \times 10^{3}$ & $\mathrm{ND}$ & $\mathrm{ND}$ \\
P. aeruginosa & $6.2 \times 10^{8}$ & $5.2 \times 10^{5}$ & $4.8 \times 10^{4}$ & $1.5 \times 10^{1}$ & $\mathrm{ND}$ \\
E. feacalis & $6.4 \times 10^{8}$ & $8.9 \times 10^{6}$ & $4.8 \times 10^{4}$ & $\mathrm{ND}$ & $\mathrm{ND}$ \\
Bacillus spp. & $3.6 \times 10^{8}$ & $3.9 \times 10^{8}$ & $4.3 \times 10^{8}$ & $4.8 \times 10^{9}$ & $6.0 \times 10^{10}$ \\
\hline
\end{tabular}

$\mathrm{ND}=$ Not detected, $\mathrm{cfu} / \mathrm{mL}=$ colony forming unit per milliliter.

Table 3: Proximate composition (\%) of pigeon pea condiment from wild fermentation.

\begin{tabular}{ccccccc}
\hline Duration (h) & Moisture & Protein & Fat & Fibre & Ash & Carbohydrate \\
\hline 0 & $10.1 \pm 0.2^{\mathrm{c}}$ & $16.6 \pm 2.1^{\mathrm{d}}$ & $6.9 \pm 0.1^{\mathrm{a}}$ & $6.6 \pm 0.2^{\mathrm{a}}$ & $1.7 \pm 0.1^{\mathrm{c}}$ & $62.0 \pm 1.4^{\mathrm{a}}$ \\
24 & $18.9 \pm 0.1^{\mathrm{b}}$ & $17.0 \pm 0.0^{\mathrm{c}}$ & $5.8 \pm 0.1^{\mathrm{b}}$ & $5.9 \pm 0.1^{\mathrm{b}}$ & $1.8 \pm 0.1^{\mathrm{c}}$ & $52.2 \pm 0.0^{\mathrm{c}}$ \\
48 & $20.3 \pm 0 .^{\mathrm{la}}$ & $17.5 \pm 0.0^{\mathrm{b}}$ & $5.7 \pm 0.1 \mathrm{~b}^{\mathrm{c}}$ & $5.2 \pm 0.3^{\mathrm{c}}$ & $3.9 \pm 0.0^{\mathrm{a}}$ & $55.1 \pm 0.2^{\mathrm{b}}$ \\
72 & $20.3 \pm 0.1^{\mathrm{a}}$ & $18.7 \pm 0.0^{\mathrm{a}}$ & $5.7 \pm 0.0 \mathrm{~b}^{\mathrm{c}}$ & $5.2 \pm 0.2^{\mathrm{c}}$ & $3.2 \pm 0.3^{\mathrm{b}}$ & $53.5 \pm 0.1 \mathrm{~b}^{\mathrm{c}}$ \\
96 & $20.1 \pm 0.3^{\mathrm{a}}$ & $19.0 \pm 0.0^{\mathrm{a}}$ & $5.5 \pm 0.1^{\mathrm{c}}$ & $5.1 \pm 0.1^{\mathrm{c}}$ & $3.9 \pm 0.1^{\mathrm{a}}$ & $49.9 \pm 0.2^{\mathrm{d}}$ \\
\hline
\end{tabular}

Values are means \pm S.D. $(\mathrm{n}=3)$. Means with the same superscript within the same column are not significantly different $(p \geq 0.05)$.

food enhances fermentation rate, as can be observed with the $72 \mathrm{~h}$ controlled fermentation in this study. Additionally, if these starter organisms are used in the right proportions, it guarantees consistency, product safety, and quality (Balogun et al., 2017).

A steady decrease was obtained in the crude fat of pigeon pea condiment produced using wild and controlled fermentations (Tables 3 and 4). The decrease in fat content may be because of some lipolytic enzymes released during fermentation, thus hydrolyzing fat to glycerol and fatty acid. There is therefore the likelihood that some of the microorganisms possessed some lipolytic property. This hypothesis is plausible going by the report by Olasupo et al. (2016) that approximately $97 \%$ of the proteolytic Bacillus species involved in the fermentation of some bean seeds were also lipolytic. It however appears that the rate of this lipolytic reactions notably declined as fermentation progressed, since the reduction in fat content, aside being significant after the first day of wild or controlled fermentation, remained almost the same throughout the rest of the period. The result obtained in this study is consistent with the findings of Adebowale and Maliki (2011) who reported decrease in the fat content of pigeon pea seed flour with increasing fermentation period.

Ash content of fermented pigeon pea increased for both wild and controlled fermentations, respectively (Table 3 and 4). Since ash represents the total of mineral contents in food, it can be suggested that some minerals were released from their complexes as fermentation advanced. The effect of fermentation on some of the antinutrients in the pigeon pea seeds could explain this result. For example, the levels of phytates and oxalates, which are known to 


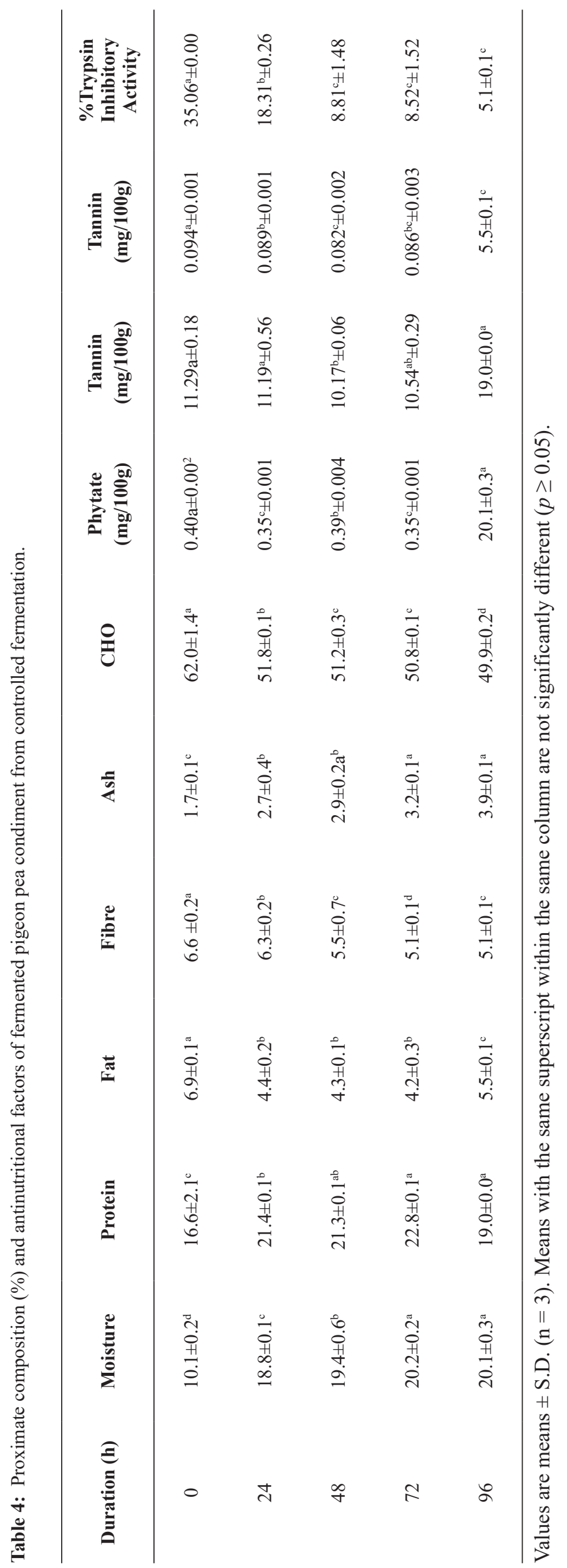


form complexes with certain types of minerals (Silva and Bracarense, 2016), reduced in line with the progress of fermentation (Table 4). It was therefore expected that more minerals would become more bioavailable in the fermented samples. A recent study by Nnennaya et al. (2020) also found that ogiri (a type of condiment) produced from sandbox (Hura crepitans) seeds steadily increased in ash with increasing fermentation time.

Carbohydrates were the most abundant macronutrient in the pigeon pea condiments (Tables 3, 4), despite their steady reduction during fermentation. There are reports in literature where the predominance of carbohydrate in fermented leguminous seeds is highlighted (Olasupo et al., 2016; Fowoyo, 2017; Ajatta et al., 2018). Reduced carbohydrate in the fermented pigeon pea may be associated with its transformation and utilisation by fermenting microorganisms. Nnennaya et al. (2020) posited that some of these microorganisms produce amylotic enzymes which are capable of hydrolysing complex carbohydrates into simple sugars. These sugars can then serve as a carbon source for energy generation and biosynthesis of some other needed compounds for growth and metabolism (Ajatta et al., 2018).

Similarly, the crude fibre of the pigeon pea experienced a general reduction during wild or controlled fermentation (Table 3, 4). This may also be associated with enzymatic activities of the fermenting microorganisms as suggested by Ajatta et al. (2018) who found a decrease from 5.55 to $3.92 \%$ for kidney beans. Crude fibre contents obtained for fermented pigeon pea in this study are higher than the $2.50 \%$ reported for fermented African laburnum seed (Cassia sieberiana) in the production of dawadawa batso (Aliero et al., 2013).

\section{Antinutrients of fermented pigeon pea condiment}

There was a significant reduction in the antinutrients of the fermented pigeon pea seeds throughout the fermentation period (Table 4). This reduction in antinutrients is consistent with the findings of researchers that fermentation helps in the reduction of antinutrients in fermented foods (Balogun et al., 2015). Phytate and trypsin inhibitor are antinutritional factors of concern in most plant foods (Balogun et al., 2019). Phytates, for example, form insoluble complexes with zinc, iron, copper and calcium thereby limiting the absorption of these minerals while trypsin inhibitor reduces protein digestibility in the body (Balogun et al., 2019). Antinutrients constitute one of the major factors limiting the utilisation of legumes. Therefore, processing operations, like fermentation in this study, which reduce these nutritionally undesirable food components, are required.

\section{Sensory attributes of pigeon pea condiment}

There was a significant $(p<0.05)$ difference between soups prepared from the fermented pigeon pea condiments (from wild or controlled fermentation) and a common indigenous commercial condiment (iru) in terms of taste, texture, aroma and general acceptability (Table 5). Panelists' ratings for pigeon pea condiment in terms of colour (6.10) and texture (6.35) were higher than those obtained for the commercial condiment although the latter was more generally accepted. This may be attributed to the panelists' familiarity with the commercial condiment. Consumers rarely readily prefer a new food product to an already existing familiar one (Akintayo et al., 2020). Pigeon pea condiment from controlled fermentation gave a significantly $(p<0.05)$ better soup in terms of texture, taste, and overall acceptability than did sample from wild fermentation. This tends to agree with an earlier report that products from controlled fermentation are superior in quality to those from natural wild process (Balogun et al., 2017). The mean score for texture (6.35) obtained in this study is similar with the findings of Balogun et al. (2018) for watermelon condiment.

\section{CONCLUSION}

The study revealed the potential of the use of pigeon pea seeds in the production of condiment using wild and controlled fermentations. Six microorganisms were isolated from wildly fermented pigeon pea and these include Lactobacillus lactis, Bacillus spp., Escherichia coli, Staphyloccocus aureus, Escherichia feacalis and Pseudomonas aeruginosa. The use of a mixed culture containing Bacillus sp and Lactobacillus sp. for controlled fermentation of pigeon pea yielded a higher crude protein than those involving pure cultures of these organisms. Crude protein, ash and moisture contents increased significantly while $\mathrm{pH}$, crude fibre, crude fat and carbohydrate decreased with increase in fermentation period. There was a reduction

Table 5: Sensory scores of fermented pigeon pea condiment.

\begin{tabular}{cccccc}
\hline Sample & Colour & Taste & Texture & Aroma & General acceptability \\
\hline Control & $5.84^{\mathrm{b}}$ & $6.35^{\mathrm{a}}$ & $5.90^{\mathrm{a}}$ & $5.95^{\mathrm{a}}$ & $6.30^{\mathrm{a}}$ \\
AWF & $6.10^{\mathrm{a}}$ & $5.26^{\mathrm{c}}$ & $6.18^{\mathrm{c}}$ & $5.40^{\mathrm{b}}$ & $5.55^{\mathrm{c}}$ \\
ACF & $6.12^{\mathrm{a}}$ & $5.45^{\mathrm{b}}$ & $6.35^{\mathrm{b}}$ & $5.41^{\mathrm{b}}$ & $5.63^{\mathrm{b}}$ \\
\hline
\end{tabular}

Means along the same column not having the same superscript are significantly different $(p \geq 0.05)$. Control - commercial locust bean condiment (iru); AWF - Fermented pigeon pea condiment from wild fermentation and ACF - Fermented pigeon pea condiment from controlled fermentation. 
in all the antinutrients as fermentation progressed. Sensory evaluation showed that the fermented pigeon pea condiment was most preferred in colour and texture when compared with a common commercial condiment (iru), making it a promising alternative.

\section{ACKNOWLEDGEMENT}

The authors wish to thank the technologists in the Departments of Home Economics and Food Science and Microbiology, University of Ilorin, Nigeria.

\section{DECLARATION OF CONFLICT OF INTEREST}

The authors disclose no conflict of interest whatsoever.

\section{REFERENCES}

A.O.A.C. (2005). Official Methods of Analysis of AOAC International, 18th edn. Gaithersburg, M.D.

Achi, O. (2005). Traditional fermented protein condiments in Nigeria. African Journal of Biotechnology 4(13): 1612-1621.

Adebayo, F.O., Adamu, M.O. and Salaam, R.B.A. (2018). Microbiological, proximate and organoleptic analyses of a fermented condiment made from seeds of Citrullus lanatus (Watermelon). South Asian Research Journal of Natural Products 1(1): 1-7.

Adebowale, O. and Maliki, K. (2011). Effect of fermentation period on the chemical composition and functional properties of pigeon pea (Cajanus cajan) seed flour. International Food Research Journal 18(4): 1329-1333.

Afolabi, F.T., Abdulkadir, M. and Onilude, A.A. (2016). Isolation and screening of microorganisms associated with locust bean (iru) for the ability to ferment soya bean to produce soy Iru. Microbiology Research Journal International 13(6): 1-10.

Ajatta, M.A., Olaoye, B.M. and Enujiugha, V.N. (2018). Biochemical changes during fermentation of kidney beans for production of condiment. $4^{\text {th }}$ Regional Food Science and Technology Summit (REFOSTS), Akure, Ondo State Nigeria, Pp 24 - 32.

Akande, K., Abubakar, M., Adegbola, T., Bogoro, S. and Doma, U. (2010). Chemical evaluation of the nutritive quality of pigeon pea [Cajanus cajan (L.) Millsp.]. International Journal of Poultry Science 9(1): 63-65.

Akintayo, O.A., Hashim, Y.O., Adereti, A.G., Balogun, M.A., Bolarinwa, I.F., Abiodun, O.A., Dauda, A.O., Solaja, A.A. and Alabi, O.F. (2020). Potentials of rice as a suitable alternative for the production of ogi (a cereal-based starchy fermented gruel). Journal of Food Science 85(8): 2380-2388. DOI: https://doi. org/10.1111/1750-3841.15334.

Aliero, A.A., Ibrahim, A.D., Ibrahim, M.L. and Abdulkareem, K.A. (2013). Effects of processing methods on the nutritional quality of 'dawadawan botso' a condiment) produced from cassia sieberiana seeds. International Journal of Science and Technology 8(3): 490-498.

Astuti, M.P. (2016). Isolation, characterization, and identification of lactic acid bacteria from chicken waste faeces that potential as probiotics. International Journal of Scientific and Research Publications 6: 180-191.

Azokpota, P., Hounhouigan, D. and Nago, M. (2006). Microbiological and chemical changes during the fermentation of African locust bean (Parkia biglobosa) to produce afitin, iru and sonru, three traditional condiments produced in Benin. International Journal of Food Microbiology 107(3): 304-309. DOI: https:// doi.org/10.1016/j.ijfoodmicro.2005.10.026.

Balogun, M., Oyeyinka, S., Kolawole, F., Joseph, J. and Olajobi, G. (2019). Chemical composition and sensory properties of soy-tiger nut cheese. Ceylon Journal of Science 48(4): 353-358. DOI: http://doi.org/10.4038/ cjs.v48i4.7676.

Balogun, M. and Oyeyiola, G. (2011). Microbiological and chemical changes during the production of okpehe from Prosopis africana seeds. Journal of Asian Scientific Research 1(8): 390-398.

Balogun, M. and Oyeyiola, G. (2012). Changes in the nutrient composition of Okpehe during fermentation. Pakistan Journal of Nutrition 11(3): 270-275.

Balogun, M., Oyeyiola, G. and Kolawole, F. (2014). Physicochemical and sensory characteristics of fermented seeds of Prosopis africana. Ethiopian Journal of Environmental Studies and Management 7(4): 411-422.

Balogun, M.A., Akintayo, O.A., Kolawole, F.L., Karim, O.R., Rowland, E. and Olalere, M.O. (2018). Physicochemical changes of Citrullus lunatus (watermelon) seeds during Bacillus species mediated fermentation and sensory evaluation of condiment produced. Centrepoint Journal (Science Edition) 24(2): 39-54.

Balogun, M.A., Oyeyiola, G. and Kolawole, F.L. (2017). Comparative study of physicochemical analysis of prosopis africana seeds fermented with different starter cultures. Croatian Journal of Food Science and Technology 9(1): 25-30. DOI: https://hrcak.srce. $\mathrm{hr} / 182637$.

Balogun, M.A., Oyeyiola, G.P., Omojasola, P.F., Kolawole, F.L., Oyeyinka, S.A., Abdulsalam K.O. and Sanni, A. (2015). Effect of softening agents on the chemical and anti-nutrient compositions of fermented Prosopis africana seeds. Carpathian Journal of Food Science and Technology 7(2): 115-123.

Ben-Harb, S., Saint-Eve, A., Panouillé, M., Souchon, I., Bonnarme, P., Dugat-Bony, E. and Irlinger, F. (2019). Design of microbial consortia for the fermentation of pea-protein-enriched emulsions. International Journal of Food Microbiology 293: 124-136.

Chukwu, O., Orhevba, B. and Mahmood, B.I. (2010). Influence of hydrothermal treatments on proximate compositions of fermented locust bean (dawadawa). Journal of Food Technology 8(3): 99-101.

Compaoré, C.S., Nielsen, D.S., Ouoba, L.I.I., Berner, T.S., Nielsen, K.F., Sawadogo-Lingani,H., Diawara, B., Ouédraogo, G.A., Jakobsen, M., Thorsen, L. (2013). Co-production of surfactin and a novel bacteriocin by Bacillus subtilis subsp. subtilis $\mathrm{H} 4$ isolated from 
Bikalga, an African alkaline Hibiscus sabdariffa seed fermented condiment. International Journal of Food Microbiology 162: 297-307.

David, O.M. and Aderibigbe, E.Y. (2010). Microbiology and proximate composition of ogiri, a pastry produced from different melon seeds. New York Science Journal 3(4): 18-27.

Enujiugha, V.N. (2010). The antioxidant and free radicalscavenging capacity of phenolics from African locust bean seeds (Parkia biglobosa). Advances in Food Sciences 32(2): 88-93.

Fowoyo, P. (2017). Microbiological and proximate analysis of Okpehe, a locally fermented condiment. Food and Nutrition Journal 2017(6): 153. DOI:10.29011/25757091. 100053.

Jaffe, C. (2003). Analytical Chemistry of food. Blackie Academic and Professional, New York, 200.

Krieg, N.R. and Holt, J.G. (1984). Bergey's Manual of Systematic Bacteriology. Baltimore, Md: Williams and Wilkins, Pp 20 - 103.

Mathews, C. and Saxena, K. (2005). Prospects for pigeonpea cultivation in drought-prone areas of South Africa. Proceedings of the First International Edible Legume Conference in Conjunction with the IVth World Cowpea Congress, Durban, South Africa, 45-53.

Munro, A. and Bassir, O. (1969). Oxalate in Nigerian vegetables. West African Journal of Biology and Applied Chemistry 12(1): 4-18.

Nnennaya, A.N., Kate, E.C., Evelyn, B.N., Godswill, A.C., Linda, A.C., Julian, I.C. and Moses, O. (2020). Study on the nutritional and chemical composition of ogiri condiment made from sandbox seed (Hura crepitans) as affected by fermentation time. GSC Biological and Pharmaceutical Sciences 11(2): 105-113.

Odion-Owase, E., Ojokoh, A. and Oyetayo, V. (2018). Effect of different fermentation methods on the microbial and proximate composition of pigeon pea (Cajanus cajan). Microbiology Research Journal International 23(1): $1-6$.
Olagunju, O.F., Ezekiel, O.O., Ogunshe, A.O., Oyeyinka, S.A. and Ijabadeniyi, O.A. (2018). Effects of fermentation on proximate composition, mineral profile and antinutrients of tamarind (Tamarindus indica L.) seed in the production of daddawa-type condiment. LWT - Food Science and Technology 90: 455-459. DOI : doi.org/j.lwt.2017.12.064.

Olanbiwoninu, A. and Odunfa, S. (2018). Microbial interaction in selected fermented vegetable condiments in Nigeria. International Food Research Journal 25(1): 439-445.

Olasupo, N.A., Okorie, C.P. and Oguntoyinbo, F.A. (2016). The biotechnology of ugba, a Nigerian traditional fermented food condiment. Frontiers in Microbiology 7: 1153. DOI: doi.org/10.3389/fmicb 2016.01153.

Omoboyowa, D.A., Otuchristian, G., Danladi, G.J., Ephraim, C., Igara, K.C.N., Okon, M.U. and Agbo, F.A. (2015). Evaluation of chemical compositions of Citrulus lanatus seed and Cocos nucifera stem bark. African Journal of Food Science and Technology 6(3): $75-83$.

Oyarekua, M. (2011). Biochemical and microbiological changes during the production of fermented pigeon pea (Cajanus cajan) flour. African Journal of Food Science and Technology 2(10): 223-231.

Prokopet, G. and Unlenbruck, K. (2002). Protectine eine nen kalsse anti-kowperahlich verbindungen dish. GesHeit, 23: 318-319.

Sharma, S., Agarwal, N. and Verma, P. (2011). Pigeon pea (Cajanus cajan L.): a hidden treasure of regime nutrition. Journal of Functional and Environmental Botany 1(2): 91-101.

Silva, E.O. and Bracarense, A.P.F. (2016). Phytic acid: from antinutritional to multiple protection factor of organic systems. Journal of Food Science 81(6): R1357-R1362.

Tamang, J.P., Thapa, N., Tamang, B., Rai, A. and Chettri, R. (2015). "Microorganisms in fermented foods and beverages, Chap. 1," in Health Benefits of Fermented Foods ed J. P. Tamang, (New York, NY: CRC Press, Taylor and Francis Group), 1-110. 